\title{
Do Twitchy Airways Accelerate the Bad Effects of Smoking?
}

\author{
Neil S. Cherniack \\ New Jersey Medical School, Newark, N.J., USA
}

Smoking cigarettes is now well established as the major predisposing factor to emphysema. But only a fraction of smokers will develop emphysema or any other form of chronic obstructive pulmonary disease (COPD). On the average, the decline in $\mathrm{FEV}_{1}$ in cigarette smokers is only $10 \mathrm{ml}$ greater for each pack-year of smoking than in nonsmokers [1]. However, in a subgroup, cigarette smoking produces a much more rapid and severe decline in lung function [2].

There have been many attempts over the years to try and identify those individuals who are particularly susceptible to the injurious effects of smoking with the idea that this might lead to treatments that would slow or reverse the adverse effects of smoking. All considered, given the poor success rate of antismoking programs, up until now, this approach warrants further study $[3,4]$.

A number of different factors seem to increase susceptibility to cigarette smoking injury. These include defects in lung defense mechanisms, twitchy airways that respond supernormally to bronchodilators and bronchoconstrictors, abnormalities in antiprotease function, occupational exposure to noxious dusts and gases, and air pollution through the relative importance of each of these factors is still arguable.

\begin{tabular}{ll}
\hline KARGER & ( 1999 S. Karger AG, Basel \\
0025-7931/99/0666-0493\$17.50/0 \\
$\begin{array}{l}\text { Fax +4161306 1234 } \\
\text { E-Mail karger@karger.ch } \\
\text { www.karger.com }\end{array}$ & $\begin{array}{l}\text { Accessible online at: } \\
\text { www.karger.com/journals/res }\end{array}$
\end{tabular}

It has been suggested for a long time that increased bronchial reactivity predisposes to accelerated loss of lung functions. The results of epidemiologic studies have been mixed with some studies supporting while other studies deny the importance of airway hyperreactivity $[5,6]$.

The paper by Stănescu et al. [7] in this issue of Respiration found no influence of the magnitude of the bronchodilator response on the decline in $\mathrm{FEV}_{1}$ in smokers and former smokers if the initial $\mathrm{FEV}_{1}$ is considered. It has long been known that individuals who smoke and have already developed $\mathrm{FEV}_{1}$ decreases are much more likely to have an accelerated decline in $\mathrm{FEV}_{1}$ and also to have enhanced bronchoreactivity when tested with either bronchodilators or constrictors. Infection and inflammation resulting from emphysema may produce a real increase in bronchoreactivity but in addition, because of smaller airways, those with lower $\mathrm{FEV}_{1}$ may display an apparent increase in reactivity simply because of the way reactivity is expressed. Thus it has been difficult to decide whether airway hyperreactivity in COPD is in fact a cause or a result of the disease [6].

While the study by Stănescu et al. adds to the data indicating no real adverse effects of bronchial reactivity, it suffers from many of the same defects as previous studies. Only a small number of subjects were studied even though

\footnotetext{
Neil S. Cherniack, MD Office of the Dean

UMDNJ - New Jersey Medical School

185 South Orange Avenue

Newark, NJ 07103-2714 (USA)
} 
for an impressive length of time. If enhanced airway reactivity is a risk factor for COPD, early treatment might help.

Thus far there are no good data supporting the idea that bronchodilators, steroids or other anti-inflammatory drugs can slow the effects of smoking on lung function. It seems that the effects of these agents are likely to be absent or small, but more work is needed to determine whether their use is useful and cost-effective. But even more important, we need improved methods of smoking cessation.

\section{References}

1 Doll R, Peto R, Wheatley K, et al: Mortality in relation to smoking. 40 years of observation on male British doctor. Br Med J 1994;309:901911.

2 Anthonisen NR, Connett J, Kiley J, et al: Effects of smoking intervention and the use of inhaled anticholinergic bronchodilator on the rate of decline of $\mathrm{FEV}_{1}$ : The Lung Health Study. JAMA 1994;272:1497-1505.
3 Wald NJ, Hackshaw AK: Cigarette smoking: An epidemiological overview. Br Med Bull 1996;52:3.

4 Hurt RD, Sachs DPL, Glover ED, et al: A comparison of sustained release bupropion and placebo for smoking cessation. $\mathrm{N}$ Engl $\mathrm{J}$ Med 1997;337:1195-1202.

5 Vollmer WM, Johnson LR, Buist AS, et al: Relationship of response to a bronchodilator and decline in forced volume in one second in population studies. Am Rev Respir Dis 1985; 132:1186-1193.
6 Anthonisen NR: Prognosis in chronic obstructive pulmonary disease: Results from multicenter clinical trials. Am Rev Respir Dis 1989; 140:S95-S99.

7 Stănescu D, Veriter C, Sanna A: In long-term smokers and former smokers the bronchodilator response is not related to the fall in FEV. Respiration 1999;66:501-505. 